\title{
On the Current Situation and Strategies to Train Practical Translation Talents
}

\author{
Wen Qin \\ Jiangxi Science \& Technology Normal University, Nanchang, 330013, China \\ shuimuxintaizi@163.com
}

Keywords: Practical translation talents; Training; Research; Strategies

\begin{abstract}
In the current situation, the market demand for applied translators is growing. The traditional model to train translation talents has been unable to meet the current social development, so it is necessary to cultivate a new model to train translation talent. We mainly start the analysis and research from the demands and requirements on the translation talent market, compare and study the traditional model to train translation talents, and put forward that in the cultivation of applied translation talents under the new circumstance, attention should be paid to the construction of practical English-Chinese translation textbooks that are suitable for regional economic development, and curriculum setting must be changed to highlight the proportion of practical teaching and professional knowledge and construct an on-campus and off-campus translation practice teaching platform that combines teaching and industry. Enhance the construction of double-certificated translation teaching faculty and adopt project system teaching methods for teaching and adapt to local conditions to improve the quality of translation teaching and meet the social requirements for multi-level and diversified applicable translation talents.
\end{abstract}

\section{Introduction}

With the constant deepening of China's political, economic, scientific and technological and cultural exchanges and cooperation, the market demand is higher and higher, and requirements for practical translation talents are also diversified. In order to keep up with the pace of the times, in the past ten years, China's Ministry of Education has approved the undergraduate translation professional pilot. The master's degree in translation has also been established, but the current translation of talent training or cannot fully meet the translation industry and even the entire language services industry, high-end translation of the demand for talent. From the data of China Translation Association, China's current translation practitioners have reached nearly 500,000, but the professional translators are only about 60,000, and these people are concentrated in Beijing, Shanghai, Guangzhou and other more developed areas. Many professional translators have a gap of up to $90 \%$. In the following, we will discuss the needs and requirements of the translation of the talent market and discuss the effective ways of translating personnel training and exploring the new forms of applied translation talents, aiming at the long-term change to improve the shortage of applied translation talents.

\section{Defects in the Traditional Models to Train Translation Talents}

With the development and progress of China, the demand for applied translation talents is more and more urgent. The reason why the translation talents are so short is mainly because the traditional translation talents training program can hardly meet the needs of the translation industry, and translation personnel training and market demand are in a serious disjointed state, which is mainly reflected in the following areas:

Traditional Translation Textbooks Focus More on Literary Translation with a Lack of Practicability and Professionality. In the teaching of translation, China's long-term teaching materials and the choice of language and literature, but also on other practical themes involved is also very few. In recent years, although the number of translation materials has continued to increase, but 
the main content of the subject matter and application of the subject matter of the proportion is still very small. Facts have proven that China only needs a small amount of translation personnel of the literary and linguistic direction engaged in teaching and research work every year, but requires a lot of foreign language and other professional, such as economy, trade, law, news, diplomacy, engineering and other composite applications type of translation talent. These emphases on literary genre translation teaching materials and translation classroom teaching model is difficult to meet the needs of the local community development. The graduates who have cultivated these graduates are very difficult to get the graduates of the English majors because of the lack of other professional knowledge, and the embarrassing situation of the high level of application of new translators is very difficult.

Traditional Translation Curriculum System is Not Perfect. First of all, we need to understand that translation is a very practical skill, so it is necessary to spend a lot of time to practice and explore it for improvement. However, in the traditional translation curriculum system, because the time of classroom teaching is very limited, translation teaching is generally limited to the theory of translation and basic translation skills, for the practice of teaching are very weak, and the translation theory of the class is very Many students have the opportunity to practice translation is quite small, this will lead to graduation, the students are remembered the translation of knowledge, but did not really practice the ability to translate cannot become a qualified translator. Of course, some of the Ministry of Education may approve undergraduate translation professional pilot, and translation master degree is already established. However, the translation of professional teaching in China's starting time is relatively late, is still in a stage of exploration, its teaching model has yet to be improved, but also follow the traditional foreign language professional translation teaching mode. So, even if the scale of translation teaching has been expanded, the number of students has increased, but the actual translation level of students and the ability of practical translation have not been improved. This model is very detrimental to the development of translators, and the traditional translation of personnel training system is not perfect, which means not enough attention is paid to the importance of practical teaching.

There is a Lack of Teaching Team for the Double-Certificated Translation Teaching. The so-called double-certificated teacher means that teachers need to have not only a solid basic theoretical knowledge and a higher level of teaching, but also strong professional practice and a wealth of practical experience. The development of translation teaching and the translation of teachers are closely linked. Application-oriented translator training is called "double-certificated" and "applied" translation teachers are required to have a wealth of translation theory and related industry knowledge, but also the practical translation ability and translation practice experience. But the reality is that a lot of teachers begin to be engaged in translation teaching work immediately after graduation without undergoing professional and vocational training in translation without practical translation work experience, its practical teaching ability is very weak. In addition, many translation teachers are the traditional English language and literature education under the background of personnel training with no relevant business, industry knowledge and experience. Therefore, the current common phenomenon in our country is that many teachers engaged in the teaching of translation courses have a lot of solid translation theory, but lack the knowledge of relevant enterprises, practical translation skills and practical experience in translation, that is, double-certificated teachers are very few, there is no way to meet the complex, applied translation of personnel training needs.

\section{Establish a New Market-Oriented Model to Train Translation Talents}

As mentioned earlier, with the social and political, economic, cultural and other areas of communication and cooperation tendencies, the community for the application of translation personnel requirements are getting higher and higher. TV social talent training and enterprise employers are completely out of touch, so there is a shortage of high-level professional translation personnel. Therefore, to solve the contradiction between supply and demand translation, cultivate 
high-quality application and practical type of translation personnel need to start from the following aspects:

Reform Teaching Textbooks. We should understand that translation teaching and translation of personnel training must first have a good teaching materials, teaching materials for students is a very important tool, because the teaching material inside the teaching content is the most important basis for the design and implementation of teaching activities, that is to say Students are mainly involved in translation knowledge and industry knowledge and improve translation practice ability is mainly through teaching materials. Then the current translation of the world more than $90 \%$ of the total is the application of the translation of the problem, a lot of translation materials should be the focus of the preparation of the transfer, to the main application-based translation. The content of the new textbook should be kept up with the times. The contents of the teaching materials should also fully reflect the needs of the contemporary social economy, science and technology, politics and cultural development, and the need for the design of diplomatic relations, trade, advertising and law, news, technology and other application issues to achieve translation, and the need to increase the proportion of applied style, the need to improve the students' practical translation capabilities, to the future translation work to lay a solid foundation.

Optimize the Curriculum System Structure and Highlight Key Points of Teaching. In order to cultivate practical talents and achieve ideal teaching effect, it is necessary to scientifically and reasonably arrange and implement application course exercises. According to statistics, the social requirements for professional translators are reflected in the several following aspects: Have certain ability to translate; Have computer application ability; Have IT knowledge; Have relevant translation experience; Have one's own language style; Have certain learning ability; Have certain professional quality; Have teamwork spirit; Have certain ability to operate software; Have corresponding translation skills; Have relevant professional knowledge; Have qualifications; Able to use trados; Have certain cultural awareness.

These are the social enterprise employing units of modern application-oriented translation of the relevant needs of talent, of course, the proportion of demand in all aspects is not the same. Most companies are more influential in bilingual translation and translation experience, as well as professionalism and related expertise; a few companies value IT knowledge and software localization and language style. It is necessary to pay attention to practice rather than attach importance to theory; all to the needs of the market as the main guide, to build a bilingual structure of the structure of the teaching Skills and translation knowledge as well as translation skills, as well as professional knowledge and integrated literacy, aids in the use of the curriculum architecture, highlighting the curriculum, setting translation practice skills and expertise.

Introduce Corporate Projects and Construct Practical Translation Teaching Platform. To improve students' practical ability of translation, it is necessary to have good translation theory and method of guidance, but also have a good practice environment to exercise. The construction of practical teaching platform is to improve the quality of practical teaching, and strengthen the effective protection of students' practical ability. And the cultivation of high-quality applied talents first need to strengthen the school's computer-assisted translation training room construction, to build an advanced translation teaching network platform, and to show students the real translation of the case and materials for students to learn, to the students Training to provide good protection. In addition to the cultivation of talent also need a variety of ways and enterprises to establish a cooperative relationship, according to the application of translation personnel training needs, build a combination of production and teaching outside the translation training base. Schools and enterprises should work together to develop out-of-school training management approach, to develop a training syllabus to determine the relevant teaching content, the establishment of a steering group to guide and solve the students in practice encountered various problems, so that students through This practice of training to develop students to cultivate, familiar with the translation of the process, access to specific translation of practical experience, the overall improvement of professional quality and comprehensive ability. 
Strengthen the Construction of Double-Certificated Translation Teaching Team. The teacher is the planner and organizer of all the activities, so there is a good teacher will train good talent. So the quality of teachers to determine the effectiveness of this teaching. The cultivation of applied translators is the need for a high-quality applied translation teacher team. Because the application of translation talents is not only to cultivate students 'ability to translate theoretical knowledge, but also need to focus on the cultivation of students' practical ability. Therefore, the process of cultivating talents in colleges and universities should fully understand the importance of double-certificated teachers in the cultivation of applied translators, and strive to improve the teachers' ability and comprehensive quality, strengthen the training of teachers' professional knowledge and promote teachers' professional level As well as the improvement of comprehensive ability, and allow teachers and employers to cooperate and exchange, so that teachers broaden their horizons, with more extensive professional knowledge and strong teaching practice ability to create a high-quality high-capacity double-certificated teachers The In fact, the construction of double-certificated faculty is not only a basic guarantee for the application of translation talents, but also for the development of colleges and universities is also of great benefit. It is also the key to improving the quality of personnel training.

Adopt the Three-Leveled "Project Teaching Method". In order to change the traditional teaching mode of "teacher speaking and student listening" for a long time, it mainly highlights the student 's subjective position, mainly adopts the students' practical needs, and adopts the three - level project teaching method teaching. What is the use of three-level collection of "project system teaching method" mean? Is to use the demonstration project, the practice project and the promotion project respectively through the entire translation teaching process, and let the students in the project operation process to study the rice mean theory and the skill, enhances the translation ability. The demonstration project is usually based on the requirements of the training program, combined with the characteristics of the translation project, the design of the corresponding scenarios, and then explain and translate the project-related translation theory and skills, and to demonstrate the relevant theory and skills in the application of the project translation so that students learn to observe and try to figure out. The practice project is done by the student in the form of a team. This is also the core of the three-level project teaching, is based on the teacher's teaching objectives and design of a small project or module to determine the specific task requirements, and by the student group form, independent search data collection, analysis to solve the problem And finally complete the translation of the entire project, through the operation of the project familiar with the operation of the translation process, to master the basic theory of Chinese and English translation and methods. The promotion project is based on their own learning situation and interest as well as the familiar industry from the main choice of translation projects, this project is mainly for those who have better academic performance, learn more students. Its purpose is to broaden the students' ideas, to provide students with a platform to self-improvement so as to achieve the goal of teaching students according to their aptitude.

\section{Conclusions}

Colleges and universities as the main base for the cultivation of translation personnel, because it has long been the kind of traditional education and training model, resulting in a lot of translation personnel training with the market completely derailed, so the traditional translation of personnel training model must be completely reform and adjustment, To truly realize the change of the training personnel training mode, so that students can graduate to cultivate, in line with the requirements of the community employing the application of translation personnel. In addition to the preparation of teaching materials need to advance with the times, highlighting the practicality and practicality of teaching materials, which the students of the actual translation ability to have a great effect. The state in the education administrative departments should be fully play a guiding role, and to keep abreast of the dynamics of the market, the development of appropriate education and teaching principles and 
policies to guide the relevant personnel training units to adapt to social development needs of applied translation talents so as to promote harmonious national and social development.

\section{Acknowledgements}

This work is supported by the 2015 Social Science Planning Project (Research on Foreign Language Teaching in Jiangxi University): Research on Tourism Text Translation based on the Functional Theory(No.15WX312).

\section{References}

[1] W.Y. Sun, C.T. Dai. Research on the training mode of skilled and applied translation talents under the cooperation of school and enterprise, Shanghai Translation, Vol. 3 (2016) No.4, p.72-76.

[2] Z.H. Zhai. Reflections on the Reform of College English Translation Teaching under the Orientation of Practical Talents, Journal of Higher Education, (2016) No.2, p.156-157.

[3] L.L. Qiu. Research on the Cultivation of Applied Translation Talents-Taking Jining College as an Example, Journal of Hubei University of Economics, Vol. 11 (2014) No.9, p.164-165.

[4] M.Y. Chai. Thinking on the Construction of Professional Translation Teaching, Chinese Translators Journal, (2010) No.1, p.46-55.

[5] L.C. Kong, H. Wang. The Dilemma and Thinking about the Development of Translation Education, Academic Degrees \&amp Graduate Education, (2011) No.8, p.48-55. 